\title{
ORIGINAL ARTICLE Current and previous eating practices among women recovered from anorexia nervosa: a qualitative approach
}

\author{
Práticas alimentares atuais e pregressas em mulheres recuperadas \\ da anorexia nervosa: uma abordagem qualitativa
}

Mariana Dimitrov Ulian', Ramiro Fernandez Unsain², Priscila de Morais Sato', Patrícia da Rocha Pereira', Isis de Carvalho Stelmo', Fernanda Sabatini', Fernanda Baeza Scagliusi'

\section{Keywords}

Eating, eating practices, eating disorders, anorexia nervosa, qualitative inquiry.

\begin{abstract}
Objective: The aim of this study was to analyze qualitatively how women, who have recovered from anorexia nervosa, perceive and describe their current eating practices, as well as the ones developed during the eating disorder period. Methods: Seven women were interviewed individually with the objective of investigating their eating practices, transition phases and all relevant aspects that somewhat contributed to the habit-forming; experiences, feelings and perceptions related to mealtime and the influence that food has had over the present subjects' life. The interviews were analyzed by the discourse of the collective subject method. Results: The results brought up the following topics: a) control; b) concerns and feelings; c) deprivation d) beauty dictatorship; e) eating competence; f) importance of food; g) food cacophony. Conclusions: What stands out is a multiplicity of eating practices, which during the eating disorder were similar to and characterized by restriction; however, after recovery, part of the subjects seem to have developed a higher eating competence, whereas others show a practice similar to the one acquired during the anorexia nervosa, such as the difficulty in realizing when they are satisfied and a feeling of discomfort when facing social interactions.
\end{abstract}

\section{RESUMO}

Objetivo: Este artigo teve como objetivo analisar qualitativamente como mulheres que se recuperaram da anorexia nervosa percebem e relatam suas práticas alimentares atuais, bem como as práticas vigentes no período do transtorno. Métodos: Foram feitas sete entrevistas individuais com mulheres que vivenciaram a anorexia nervosa. Estas abordaram: hábitos alimentares das entrevistadas; mudanças e fatores importantes para a formação destes; vivências, sentimentos e percepções associados ao momento da refeição; e a influência que a alimentação exerce na vida das participantes hoje. A análise dessas deu-se a partir da técnica do Discurso do Sujeito Coletivo. Resultados: Os resultados trouxeram os seguintes temas: a) controle; b) preocupações e sensações; c) privação d) ditadura da beleza; e) competência alimentar; f) importância da alimentação; g) cacofonia alimentar. Conclusões: Destaca-se

1 Universidade Federal de São Paulo (Unifesp), Campus Baixada Santista.

2 Universidad Nacional de Buenos Aires, Facultad de Filosofía y Letras, Cátedra de Antropologia, Buenos Aires, Argentina.

Correspondence address to: Mariana Dimitrov Ulian

Universidade Federal de São Paulo, Campus Baixada Santista

Av. Ana Costa, 95

Telephone: (13) 3878-3700

11060-001 - Santos, SP, Brazil

E-mail:mari_dimi@hotmail.com 


\section{Palavras-chave}

Alimentação, práticas

alimentares, transtornos

alimentares, anorexia

nervosa, estudo qualitativo. nesses a multiplicidade das práticas alimentares, que durante o transtorno se assemelham e se caracterizam pela restrição; no entanto, após a recuperação dos sujeitos, alguns parecem ter desenvolvido maior competência alimentar, enquanto outros apresentam práticas semeIhantes às vigentes na anorexia nervosa, além de dificuldade de perceberem quando estão satisfeitos e sensação de desconforto em situações de interação social.

\section{INTRODUCTION}

Anorexia nervosa (AN) is an eating disorder (ED) characterized by an intense and intentional weight loss resulted from a restrictive diet and by body image disturbances'.

Eating is essential for the construction of our identity since it is built biologically, psychologically, and socially through what the subject decides to incorporate ${ }^{2}$. The different meanings associated to food deprivation have changed over the years and are specific to the cultural moment on which it occurs ${ }^{3}$.

Thus, eating can trigger innumerous feelings ${ }^{2-4}$. Especially, when considering women who suffer from AN, it is documented that they show an extremely dysfunctional relationship with eating ${ }^{3}$. However, little is known as to how this relationship unfolds during the disorder and after recovery. Moreover, many consider eating and dieting as simple and set factors, and there is not enough description of how they are construed, understood and contextualized ${ }^{5}$, especially among individuals with ED.

Regarding the remission of the disease little is known about its nutritional aspects and whether they may influence its maintenance 6 . Schebendach et al. ${ }^{7}$ found that diet energy density and variety predicted outcome in recently weightrestored women with $\mathrm{AN}$. Crisp et al. ${ }^{8}$ investigated the relationship between sleep, nutrition and mood of patients with AN before and after restoring a normal weight. They concluded that changes in sleep patterns were associated with disturbances in nutritional status caused by the disease, but did not investigate which nutritional aspects might have influenced such finding. The abovementioned studies bring important findings about nutritional aspects of the postrecovery period of AN, but they evaluated only objective and quantitative parameters, which may limit the full exploration of the subject. It is hypothesized that eating practices*, when better developed, might exponentially affect patients' recovery and avoid relapses. The present study would be an initial step towards researches in this area. Exploratory qualitative researches could be hereafter conducted in order to better describe eating practices during the remission

* Eating practices were conceptualized as a set of objective and subjective data that enable description and understanding of the eating phenomena. Thus, eating practices could be defined as the way individuals relate to food in different spheres ${ }^{9}$. period, allowing quantitative studies to later investigate if these practices are associated with a better outcome.

Thus, the aim of this study was to analyze how women, who have recovered from AN, perceive and describe their current eating practices, as well as the ones prevailed during the ED.

\section{METHODS}

This research was a qualitative inquiry. It was held in the city of São Paulo (Brazil) and involved seven women who recovered from AN. The inclusion criteria were: a) to be female; b) to state to have recovered from $A N$; $c$ ) not to be engaged in any treatment for AN, and; d) to agree to enroll in the study.

Regardless of the treatment received (or not) during the AN period, all subjects reported that the initial diagnosis was made by a psychiatrist at the time. In this study, recovery was considered as the presence of normal body mass index (BMI, calculated as weight/height ${ }^{2}$, the cut-off point was BMI $\geq$ $18.5 \mathrm{~kg} / \mathrm{m}^{2}$ - data of weight and height were self-reported) and the absence of the following symptoms (self-reported and evaluated before the interviews): refusal to maintain weight within an adequate range, and the presence of purgative practices.

Information-rich cases were selected, resulting in "insights" and in depth understanding rather than empirical generalizations ${ }^{10}$. Thereby, the "snowball" and "emergent" samplings were combined.

The sampling process involved making contact with the coordination of the Network of Encouragement of Health, Body Satisfaction and Food (RISSCA), which provides information about the disease and discusses related issues. The discussions are conducted mainly by a digital platform, but also by face-to-face meetings, which are scheduled monthly. The Network provided the contact of potential participants, which were approached by e-mail or telephone. One subject interviewed had bulimia nervosa, hence was not included in the study sample. The final sample was made up of 5 participants of the network and 2 non-participant individuals that were appointed by other members (snowball sampling). To establish the total number of respondents the saturation criterion was used: when additional information no longer generates new understanding ${ }^{10}$. 
Data was collected by a semi-structured interview. This type of interview is characterized by the previous development of open-ended questions, which should encompass all the content of interest and flexibility as to allow other questions to emerge from the dialogue between researcher and subject ${ }^{11,12}$. The interview aimed at collecting information that characterized the interviewees, and at raising issues that could contrast the ED period to the recovery stage ${ }^{13}$, addressing: the eating practices of the respondents, as well as changes and factors considered important to its formation; experiences and feelings related to the mealtime; the relationship between the respondents with family and friends; situations which involved food, and its influence on their lives.

The interviews, recorded and transcribed verbatim, were conducted individually by the first author of this study (MDU), who had previous experience with qualitative interviews. When approached, participants were informed of the objective of the study, but otherwise, relationship between researcher and interviewees was not established prior to interviews. They were conducted in a place selected by the participants and lasted from 50 to 90 minutes.

From the transcribed material, the questions that best met the objectives of the study were selected to compose the final analysis. For data treatment, the Collective Subject Discourse (CSD) technique was used. It consists of a synthetic speech, derived from the analysis of the material collected by the interviews ${ }^{13}$. The technique allows finding common ideas among the selected responses. These are given a summing name, called central idea $(\mathrm{Cl})$, which are later grouped when expressing the same meaning and coded, forming the CSD ${ }^{13}$. Seven CSD were built, and then grouped into 5 tables.

The project was approved by the Ethics Committee of the Federal University of São Paulo and by the RISSCA. All participants signed the Free and Informed Consent Term before the interview.

\section{RESULTS}

Box 1 shows the socio-demographic characteristics of the interviewees. Box 2 shows information regarding the anorexia nervosa period.

Tables 1 to 5 demonstrate the $\mathrm{Cl}$ and the respective discourses obtained for each question.

\section{DISCUSSION}

The discourses brought up the following topics: a) control; b) concerns and feelings; c) deprivation d) beauty dictatorship; e) food competence; f) importance of food; g) food cacophony.
Box 1. General characteristics of seven women who had recovered from anorexia nervosa. São Paulo, Brazil, 2011

\begin{tabular}{|c|c|c|c|}
\hline Characteristic & Mean & $\begin{array}{l}\text { Standard } \\
\text { deviation }\end{array}$ & $\begin{array}{c}\text { Minimal and } \\
\text { maximal } \\
\text { values }\end{array}$ \\
\hline Age (y) & 26.8 & 4.09 & $20-33$ \\
\hline Weight (kg) & 52.5 & 4.59 & $45-58$ \\
\hline BMI $^{1}$ & 19.3 & 0.78 & $18.6-20.4$ \\
\hline Duration of the disease (y) & 4.71 & 2.96 & $1-9$ \\
\hline \multirow[t]{2}{*}{ Remission (y) } & 4.5 & 2.29 & $1-8$ \\
\hline & & $\%$ & \\
\hline \multicolumn{4}{|l|}{ Education } \\
\hline Undergraduate student & & 28.6 & \\
\hline Graduated from college & & 42.8 & \\
\hline Graduate student & & 28.6 & \\
\hline \multicolumn{4}{|l|}{ Occupation } \\
\hline Employed & & 57.2 & \\
\hline Student & & 42.8 & \\
\hline \multicolumn{4}{|l|}{ Relationship status } \\
\hline Single & & 85.7 & \\
\hline Married & & 14.3 & \\
\hline \multicolumn{4}{|c|}{ Relapses during the period after treatment } \\
\hline Yes (restrictive behaviors) & & 28.6 & \\
\hline No & & 71.4 & \\
\hline
\end{tabular}

Box 2. Characteristics of the anorexia nervosa period of seven women who had recovered from the disease. São Paulo, Brazil, 2011

\begin{tabular}{lc}
\hline Hospitalization & $\%$ \\
\hline Yes & 42.9 \\
No & 57.1 \\
Treatment & 57.1 \\
Combined treatment (dietitian, psychologist, psychiatrist) & 28.6 \\
Combined treatment (psychologist, psychiatrist) & 14.3 \\
Did not have any specific treatment & \\
Theoretical orientation used during treatment & 28.6 \\
Cognitive-Constructivist & 57.1 \\
Could not report & 14.3 \\
Did not have any specific treatment & \\
Period of live with anorexia nervosa & 42.9 \\
Adolescence & 57.1 \\
Adulthood & \\
\hline
\end{tabular}

\section{Control}

Among the etiological aspects that make up AN, the psychological ones stand out with relevant characteristics, such as perfectionism, need for control and organization. Those can be exemplified by the intense focus on details, the establishment of rules related to food, like extreme diets and calorie counting ${ }^{14}$. 
Table 1. Central ideas and the collective subject discourse of seven women who have recovered from anorexia nervosa, combining questions 1 and 2. São Paulo, Brazil, 2011

\begin{tabular}{|c|c|}
\hline \multicolumn{2}{|c|}{ Question 1: How do you experience the mealtime today? } \\
\hline Central idea & Collective subject discourse \\
\hline $\begin{array}{l}\text { 1A: It's a pleasurable } \\
\text { moment, I eat what } \\
\text { I want }\end{array}$ & $\begin{array}{l}\text { Today it's something really calm, it's a pleasurable moment, I really like eating. I allow myself much more, I understand the importance of eating. I eat what I want } \\
\text { to eat, like chocolate, bread - without the crumb - I find a way, but I eat. By eating what I like I can find pleasure. And sometimes I think it's healthy to exaggerate } \\
\text { once a week. Not exaggerate, but exceed the regular amount }\end{array}$ \\
\hline $\begin{array}{l}\text { 1B: The frequency and } \\
\text { quantity improved }\end{array}$ & $\begin{array}{l}\text { The frequency improved a lot, I eat at least six times a day; the quantity improved a lot. Even the snacks, at every three hours. I still choose healthier foods, but I } \\
\text { don't like eating small amounts anymore; if I realize that one day I ate too little, it seems I'm getting weaker. It has to be something more balanced }\end{array}$ \\
\hline $\begin{array}{l}\text { 1C:I try to eat better and } \\
\text { I don't skip meals }\end{array}$ & $\begin{array}{l}\text { I don't feel as repulsed towards food as before. Just by smelling something, I wanted to vomit, I'd put a spoon in my mouth and run straight to the bathroom. Not } \\
\text { anymore, I hate feeling hungry; if I do, I overeat, I can't control it; the feeling is terrible, I don't like it. So it's about not to stop eating. Within this chaotic world we } \\
\text { live in, where everything is kind of bad, food is artificial I try to eat the best way I can. I like food, the taste of food, without condiments, without anything; I don't } \\
\text { like things very elaborated, I like simple food. I haven't changed much the portions I eat and I haven't changed what I eat, but I enriched my diet with the treatment }\end{array}$ \\
\hline $\begin{array}{l}\text { 1D: I want to control how } \\
\text { much l eat }\end{array}$ & $\begin{array}{l}\text { I have the impetus to control how much and what I eat. I follow a routine with my diet, I try to eat at a certain time because after that my hunger goes away } \\
\text { and I don't eat the same as I could, then the despair starts, I get very irritated and anxious. Sometimes, when I go to restaurants I still feel anxious: I'm anxious } \\
\text { waiting for the food to arrive; when it arrives I hold up so I don't eat fast and a lot. Today, more or less I know how much I'Il eat, it's a security I have since I'm } \\
\text { eating everything right and I'm not destroying, killing myself anymore; it's like "wow, nice, I'm satisfying my hunger, it tastes good", I'm still like "let me see how } \\
\text { much I've eaten so far". I've learned to enjoy some things, I choose things I like from the food pyramid and I don't force myself to eat what I don't like; it was really } \\
\text { painful, it was an incredibly stressful activity for me. I almost never eat out; I always eat my food; to go out and eat food from other places it has to be a really } \\
\text { special situation, to eat natural food, vegetarian, this kind of thing, but I get irritated and anxious. Once in a while I eat my mother's food, but I always prefer mine } \\
\text { because I control what I eat. I don't like self-service restaurants; I eat at those places when there's no other option; I don't like it because I don't know how it was } \\
\text { prepared. I rather eat à la carte food, because it bothers me to see a lot of food exposed }\end{array}$ \\
\hline
\end{tabular}

1E: I prefer eating alone When I'm having lunch with friends, it's fine, but when I'm eating alone, I still feel a little ashamed. It must be some vestige from the eating disorder, because at that time, in order for me not to feel hungry I thought: "imagine something disgusting during the mealtime", sometimes I'm a little ashamed. I don't like to see others eating, I don't have patience, it disgusts me, the noise people make when eating irritates me: or they eat too fast or I eat too slowly and I'm always the last to finish. Depending on whom I'm with, I'm ashamed of eating, so I prefer eating alone so people won't see me eating. Having company has always been an issue: when I was with the anorexia, my family controlled me a lot, so when I go to a restaurant, I realize they still control me somehow and that makes me choose a different dish, pick a little more, a little less. I don't like the habit of staying at the table chatting because people keep eating and I have to control myself as much as I can while I'm talking, I don't like that very much

1F: I don't really like to I don't really like eating, it's not a priority as it once was. I choose really well what I eat; I'll eat to satisfy my hunger

eat, l eat to satisfy my

hunger

1G: I feel guilty I I feel guilty depending on the day, but sometimes I do. Sweets, a more elaborated cake, those things that everybody thinks will put on weight if they eat. And sometimes those really greasy things: depending on what it is, if it's too greasy, it seems that the grease is on me. Fried food, fried pie, French fries, make me feel guilty. And candies, because I have a very strong weakness for sweets, so I realize that if I start eating sweets that week, the following days I feel like eating it again, and each day I eat it increases my guilty feeling. I try to avoid it. I see the fat depositing, I see the pudding setting on my belly, I think it's like this, a matter of cause and effect: if l eat, I put on weight

\begin{tabular}{l} 
Question 2: How were your eath \\
\hline Central idea \\
\hline 2A: Certain thoughts \\
prevented me from \\
eating
\end{tabular}

2B: Food was poison, something really bad

\section{ing practices during the anorexia nervosa period?} Collective subject discourse

There were things I really couldn't eat, I'd put them in my mouth and it seemed they couldn't be swallowed. I'd spend all day long and I wouldn't eat, or if I did, I'd throw up. Everything was horrible. I didn't eat, I stopped eating everything I used to enjoy. When I didn't want to eat, I didn't want it and period. I was determined to lose weight and to achieve a fast result, I cut what I thought would make me fat, the little I ate I felt my stomach aching, I felt nausea and I didn't like to feel nausea, I would vomit immediately. The feeling of being with the food in my stomach was worse than the sickness. Today it is less intense for me to think "I'm eating this, I'll put on weight, I should be eating something else"; it's just that before, this refrained me from eating or made me eat less; today I eat. I was proud of putting just a little food on my plate and of not eating sweets, or anything

Food for me was terrible, I couldn't eat; I deprived myself, I didn't care whether I was eating properly or not, I ate very little; I wanted to lose weight, so, neither quantity nor quality of the food mattered. Food was something really bad for me. I wanted to deny it, but at the same time I had this duality: I didn't want to eat, but when I saw a cake I wanted to eat the whole cake. Then I'd climb the stairs thirty times. So I didn't quite understand what it was. It was neither good nor pleasant, it was something really heavy, indeed

2C:I had my meals alone I didn't eat in public and I was ashamed because I thought people would look at the size of my plate, see what I was eating. I had my meals alone and fast, it was something I wanted to quickly get over with, it was something I didn't like doing: eating, chewing. I didn't find any pleasure staying at the table talking with other people, I didn't feel well, so I'd eat and leave. It was bad, especially in parties that had a lot of food at the same time; I didn't stay and didn't participate much. I felt such panic to see that amount of food that I preferred being alone. I felt really pressed and I'd got to do my plate and go eat somewhere else, so no one could pressure me and if I realized there were a lot of people observing, I'd always eat less, never got a more normal dish. At home I could deceive: I wouldn't eat with them at the table; I'd eat in my room instead, or I'd keep playing with the dish there, throw the food away, or I'd eat and then I'd throw up, it was easier. I expected to eat alone most of the times, so I could eat only what I wanted. When I ate with them it was always that thing of checking what I was eating, leading to those horrible fights; it was complicated

2D: The meal was Before now, I'd eat three meals and occasionally, something really light, such as fruit with only a few calories or a light cereal bar. But it was basically the three incomplete meals and I'd eat a big plate of salad for lunch, and only then I would have something else; sometimes I didn't. I'd put a tiny spoon of rice and I didn't eat beans, because for me beans would make me fat, I wouldn't put any meat, not even the white one; it was basically rice, beans and the salad, a lot of it. Always salad. And the meal was very incomplete, I wasn't eating properly, but I didn't know anything about this matter, so I thought it was correct, that I could do it unrestrainedly

2E: I enjoyed feeling It took a while for me to feel hungry again, because the hunger perception is completely different with anorexia. You get to enjoy feeling hungry, so you're feeling hungry a thing your brain suddenly doesn't understand anymore as hunger. Then I'd only eat when I was feeling very weak

2F: I used to control I I I I I to control even how many tomatoes I ate. So if I was full I'd stop. I mean satisfied in quotes, because I wasn't really. It was terrible, it was a calorie counting: count how many calories here, how many there, eliminate some here. When I couldn't eat alone, it was that thing of trying to control, like "no, you don't need that, eat only this, your stomach will already be full with this"; it was torture, really

2G: I felt guilty Whatever I ate made me feel guilty. Even at meal time I'd think "I promised myself that today I would not eat anything" and ended up eating. I thought I would grow a belly, that my hips and cheeks would get bigger, and that I wouldn't lose later. Even the water I drank made me feel guilty 
Table 2. Central ideas and the collective subject discourse of seven women who had recovered from anorexia nervosa, combining questions 3 and 4. São Paulo, Brazil, 2011

\begin{tabular}{|c|c|}
\hline \multicolumn{2}{|c|}{ Question 3: How are your eating practices? } \\
\hline Central idea & Collective subject discourse \\
\hline $\begin{array}{l}\text { 3A: I avoid greasy and } \\
\text { fried food }\end{array}$ & $\begin{array}{l}\text { I'd rather not eat fried food, but when I do, I don't feel well, I feel my body can't handle it, I always try to avoid it. I try to avoid salt, greasy, and fried things. If I'm } \\
\text { making rice, for example, I prefer using olive oil, something less greasy than oil. I can eat meat, but only if it doesn't have much fat, I don't like fat, if I feel the taste } \\
\text { of it I can't swallow it }\end{array}$ \\
\hline $\begin{array}{l}\text { 3B: I seek after } \\
\text { something complete }\end{array}$ & $\begin{array}{l}\text { I seek after something complete; I check: it can't have only carbohydrates, it also has to have proteins, vegetables; otherwise, I know I'll soon feel hungry, or it } \\
\text { will result in some consequence to my body. Considering the whole day, I think it can't go without at least one fruit. Always has to have some fruit, vegetables, } \\
\text { legumes, grains, salad. When it doesn't, I feel bad; it seems I didn't have lunch. The issue nowadays is not the calorie anymore, but what that calorie adds; most } \\
\text { important is the quality of what I'm eating and know that this will be positive for me, I care about the taste. What worries me is if what I'm eating will be positive } \\
\text { for me; I began to understand that what I eat contributes to who I am; if I eat a Big Mac, a Pizza Hut, it won't resolve, it won't fulfill me, it'll be an empty calorie and } \\
\text { will generate a number of other things. There're things I don't feel like eating, that are not really good, it's not even about gaining weight }\end{array}$ \\
\hline 3C: I can eat what I want & $\begin{array}{l}\text { I can eat exactly what I want, I can eat anything; fried food is a thing that I eat without worries; I don't have issues anymore with sweets, but I used to avoid it at } \\
\text { any cost; now, at least one sweet per day. Before that, I avoided oil, avoided butter, everything; now I think like this: it's not much, because I don't make greasy or } \\
\text { fried food, so, I'm not avoiding it anymore }\end{array}$ \\
\hline $\begin{array}{l}\text { 3D: I have a trade-off } \\
\text { mechanism }\end{array}$ & $\begin{array}{l}\text { I always have a trade-off mechanism of thinking: if I eat two slices of bread instead of one for breakfast, then I won't have a snack later because I've already eaten } \\
\text { the bread that would be for snack; I always use this trade-off mechanism }\end{array}$ \\
\hline 3E: I prefer grilled meat & $\begin{array}{l}\text { I only eat "the regular meat": chicken, fish and beef; I don't eat pork, rabbit, or alligator. I'd rather eat grilled meat, but if there isn't any, I eat it anyway, but } \\
\text { nowadays, I eat it, I don't refuse it; I feel kind of weak without meat }\end{array}$ \\
\hline \multicolumn{2}{|c|}{ Question 4: Is there anything you would like to change in your eating practices? } \\
\hline Central idea & Collective subject discourse \\
\hline $\begin{array}{l}\text { 4A:I wish I had a } \\
\text { healthier and more } \\
\text { natural eating practice }\end{array}$ & $\begin{array}{l}\text { I wish I had an eating practice closer to the natural one, to the vegetarian; if I could eat more legumes, vegetables, fruit, it would be a little healthier; perhaps if I } \\
\text { modified slightly the snacks I eat, because every day it is a salty treat; I could try to switch for something healthier }\end{array}$ \\
\hline $\begin{array}{l}\text { 4B: I wish I could eat less } \\
\text { chocolate, soda, coffee, } \\
\text { gums and meat }\end{array}$ & $\begin{array}{l}\text { I wish I didn't eat that much chocolate, I wish I could stop eating meat for good. I wish I didn't drink soda, I wish I drank less coffee, chewed less gum. It's not a } \\
\text { matter of feeling guilty, but this is poison }\end{array}$ \\
\hline 4C: I wish I could eat more & $\begin{array}{l}\text { I would try to eat more, but I can't eat much. Now I'm eating enough: breakfast, lunch, a mid-afternoon snack and dinner. I eat well, I don't eat poorly, but as I have } \\
\text { this difficulty in gaining weight, I think I would have to eat more, but I can't }\end{array}$ \\
\hline 4D: I wish I could eat meat & I wish I could eat red meat, but I can't because it messes my alimentation up: if it has, I say "oh no, meat again” \\
\hline $\begin{array}{l}\text { 4E: I wish I could eat } \\
\text { homemade food }\end{array}$ & If I could, I think I would eat homemade food every day; really, it's something I miss tremendously \\
\hline $\begin{array}{l}\text { 4F: I wish I could detach } \\
\text { myself more }\end{array}$ & $\begin{array}{l}\text { I deeply wish I could eat and that this could fulfill what my body needs without thinking much about it; I wish I could detach myself more, because I feel that I still } \\
\text { think, not obsessively, but I'm always considering that what I'm eating has to be good for me }\end{array}$ \\
\hline
\end{tabular}

Table 3. Central ideas and the collective subject discourse of seven women who have recovered from anorexia nervosa, constructed by question 5. São Paulo, Brazil, 2011

\begin{tabular}{|c|c|}
\hline \multicolumn{2}{|c|}{ Question 5: Do you realize when you are satisfied? } \\
\hline Centralidea & Collective subject discourse \\
\hline 5A: It depends & $\begin{array}{l}\text { It depends a lot on the moment; there are moments when I'm very anxious, so even if I'm feeling satisfied I eat, but later I feel extremely guilty, I keep controlling myself, } \\
\text { thinking about what I'm eating the following day. It depends a lot on the food as well, there are times that I look at it and think: "what a pity to waste it", then I end up eating }\end{array}$ \\
\hline $5 B$ : It's hard to know & $\begin{array}{l}\text { It's still hard to know when I'm satisfied. Sometimes I think I'm satisfied and I'm eating the rest for greed. I think it's always been like this, not knowing exactly } \\
\text { when to eat more or less; I don't really know if I feel satisfied, I eat what's on my plate and that's it, it's over }\end{array}$ \\
\hline 5C:I stop & $\begin{array}{l}\text { Most of the times I stop when I'm satisfied; if I'm in a place that sells a set portion and I'm satisfied, I stop eating; actually, I never have seconds, I can always } \\
\text { visualize and put the same amount; if I have seconds, I feel really bad, I think I have some physical symptoms: I start feeling nausea, or something like that }\end{array}$ \\
\hline 5D: I eat everything & $\begin{array}{l}\text { I have to finish everything - it sticks to my mind: if I leave some food on the plate, it seems that right away the stomach opens a space. Then I say "no, there's no } \\
\text { room for more". So, when I finish eating, being satisfied or not, I'm done, I don't leave anything on my plate, it's always clean, always; I control the portions very well }\end{array}$ \\
\hline $\begin{array}{l}\text { 5E: I know when I'm } \\
\text { satisfied }\end{array}$ & $\begin{array}{l}\text { When I prepare my food, I kind of know how much will satisfy me. I make food accordingly; I usually take a "brown bag", so I automatically put only a little food, } \\
\text { because I don't eat much, but I eat many times a day; usually I take the exact amount }\end{array}$ \\
\hline
\end{tabular}

Table 4. Central ideas and the collective subject discourse of seven women who had recovered from anorexia nervosa, constructed by question 6. São Paulo, Brazil, 2011

Question 6: When you can choose between light, diet, organic, functional kinds of food instead of just the regular kind, do you choose them?

\begin{tabular}{ll}
\hline Central idea & Collective subject discourse \\
\hline 6 : Always & I go for the light ones. I think that if I can reduce something, there's no need to buy the regular versions. I'm not used to going shopping for the regular items; I
\end{tabular}
always go shopping for my usual things, some items that are lighter. I take the organic, the light and the diet ones, mainly because of weight concern. The organic food in particular is different, because it tastes different. I always choose the whole and light products, and if they have organic products, I choose the organic ones, even if they are more expensive, I always choose them

6B: Never I don't buy diet, light items, those things. I've never been like this - choosing those kinds of food. I haven't eaten light or diet food in a while because they're harmful; that is something I've learned from a nutritionist. Diet is for those who have diabetes and, for instance, milk I even buy the whole one, it's not an issue for me. Organic is too expensive, therefore I don't usually buy organic products. I haven't joined the organic flow

6C: It depends It depends. I check to evaluate if it's worthwhile because sometimes the light version is not that less caloric, or the calories come from nutrients, which are not necessarily, and the price rarely is much higher. I prefer choosing the light version of gelatin dessert because I see like this: "wow, the difference between them is sugar, it's all sugar" or, if I'm drinking soda, I prefer the light one because the regular version has too much sugar, but not other things. For example, light popcorn is kind of weird, so I choose the regular version. The only thing I still use, but I believe it's a matter of habit, is the sweetener: it's not because it's light, or because it's not sugar, it's just a habit

6D: I used to choose and I chose, I indeed chose: light gelatin, light condensed milk. I ate, but I didn't like it, I never really enjoyed them. For me it was like this: I can eat anything I want, then I go eat, even if I didn't like it to the washroom and I vomit it all and that's it, it's over! I said "it won't be in my stomach, so I'll eat it". I didn't deprived myself, but if I ate I threw them up 
Table 5. Central ideas and the collective subject discourse of seven women who had recovered from anorexia nervosa, constructed by question 7. São Paulo, Brazil, 2011

\begin{tabular}{|c|c|}
\hline \multicolumn{2}{|c|}{ Question 7: In which way does food influence your life today? } \\
\hline Centralidea & Collective subject discourse \\
\hline $\begin{array}{l}\text { 7A: It's something } \\
\text { natural that we need } \\
\text { every day }\end{array}$ & $\begin{array}{l}\text { I think it's both ways: the way I eat influences my life and my life influences my way of eating, because I have a lot of plans for my life, so I want my body to be well } \\
\text { for this, I want to be able to run, to have all this mobility. I want this for my life and I want to be healthy for this. Before now, it was something I wanted to avoid, I } \\
\text { didn't want to eat, I thought food was unnecessary; my dream was to create a pill that I could ingest so I wouldn't have to eat, substitute food for this; but today it's } \\
\text { something natural, I cook normally, eat normally. For me it's easy, it's part of my day, as sleeping, taking a shower, this kind of thing }\end{array}$ \\
\hline $\begin{array}{l}\text { 7B: I try to adjust to a } \\
\text { normal life }\end{array}$ & $\begin{array}{l}\text { I think I'm in a moment today when I'm trying to adjust myself to a normal life, to go out, eat that 'feijoada" with my friends and be okay, and not run straight to } \\
\text { the washroom. I'm really trying to include food in my social live and not to isolate myself thinking "I'll eat alone so nobody can see me", this is an influence }\end{array}$ \\
\hline $\begin{array}{l}\text { 7C: Food is my live, my } \\
\text { source of energy }\end{array}$ & $\begin{array}{l}\text { For me food is my live. I think that it is the same for everybody: if you don't eat you can't live, you can't accomplish your things. I think a lot about it, to accomplish } \\
\text { my future projects, because nothing will happen if I stop eating. Today, food for me is everything. I think it still influences a lot because it is my source of energy, it } \\
\text { is something I like to do, but I try to make it something positive and I like to eat, I want to feel pleasure in eating. This body is a tool for me to exist, so I have to take } \\
\text { care of it }\end{array}$ \\
\hline $\begin{array}{l}\text { 7D: It involves social } \\
\text { situations, causing } \\
\text { anxiety }\end{array}$ & $\begin{array}{l}\text { It still influences a lot because I think that many of my social situations involve food, there's always some kind of food involved and as I still have I still feel a heavy } \\
\text { load, like a big responsibility; as much as I participate of the gathering I keep controlling myself later, even if it's not at the spot. I'm a little anxious to eat at the } \\
\text { right moment and to eat the food I consider healthy }\end{array}$ \\
\hline 7E: It doesn't in anyway & $\begin{array}{l}\text { In nothing, I eat to keep myself up, that's all, because it's not at all a priority. I eat indeed to keep myself up, because I can't, I don't have time, I have a really busy } \\
\text { routine. I have lunch because I'm fainting; it's not a priority anymore, it can't be }\end{array}$ \\
\hline
\end{tabular}

${ }^{1}$ It is a stew of beans with beef and pork, a Brazilian typical dish.

Not surprisingly, the need for control stood out in the reports regarding the ED period; nonetheless, it also appeared in the period after recovery. However, there were differences in the way this control was exerted: while during the ED control was done through the quantity of food and the calories consumed (Cl 2F), after recovery the focus shifted: it turned into a need to establish a routine and a pattern related to eating practices (CI 1D).

Even though some individuals considered the mealtime as "a really calm, a pleasant moment" (CI 1A), a certain control can still be noticed in terms of quantity of food consumed (Cl 1A). Cl 3A also showed this control by means of concern related to the amount of fat contained in the food, which became an avoided component and source of aversion.

Control is a well-established characteristic of the AN dynamic. It gives a sense of certainty and security. It calls our attention that most of the subjects have received nutritional treatment, which is essential for AN. Nevertheless, depending on the kind of nutritional treatment, the biological aspects of the food are over emphasized, meaning that the need of control might persist and, also, that there might be a switch between the rigid, restrictive diet to a rigid, but adequate $\operatorname{diet}^{15}$.

As observed in the discourses of our study, control still plays a part on participants' life even after they have recovered, which suggests that recovery does not mean losing the impetus of control. Lee et $a .^{16}$ examined the relationship between control and the intermediate term outcome of patients with AN. Individuals with a good outcome had the least negative modes of control and the least desire for control. They suggest it might be necessary to better address control aspects during treatment. Such approach could have eased our participants' willingness to establish routines and a diet, and also their discontentment when not meeting certain expectations.

\section{Concerns and feelings}

During the $E D$, subjects were not concerned about having a satisfactory food consumption (Cl 2B). $\mathrm{Cl} 2 \mathrm{D}$ reports their food intake during this period, reinforcing their lack of concern with food itself, since it was regarded as something to be suppressed in order to lose weight. Differently, after they have recovered, both frequency and quantity of food improved (CI 1B). A concern with food quality could also be noted (Cl 3B).

The discourses above-mentioned highlighted negative feelings related to certain kinds of food and the consequences to the body. Besides, guilty also appeared in both moments studied (Cl 1G and 2G). The same guilty feeling is repeated in both phases: that eating would represent irreversible consequences to the body (Cl 1G).

This feeling was observed in the study of Souto and FerroBucher ${ }^{17}$ : it was reported that one grain of rice or one piece of candy would be enough to trigger the feeling of weight gain. Long et al..$^{18}$ found an ongoing concern with food during the disease period. Furthermore, food was visualized in a fragmented way: a cake was seen by its ingredients (eggs, butter and sugar), refraining the respondent from eating it. Still in this work, the speeches showed feelings of physical discomfort, identity loss and inadequacy during the meals. Anxiety, panic, confusion and shame were also described. Apart from panic, reported in a speech just during the illness period $(\mathrm{Cl} 2 \mathrm{C})$, the other feelings described could also be observed among our subjects even when recovered.

Espíndola and Blay ${ }^{6}$ argue that, in the long term, the disease involves limitations and restrictions, which may influence the level of adjustment of the individuals, even when recovered. As observed in our results, participants did not show a relaxed attitude regarding food or eating. Thus, the reported concerns and feelings may trigger an eventual relapse. An alternative would be to shift the treatment 
focus to the use of more meaningful therapeutic tools, such as restoring patients' food culture and investing on the emotional and social functions that permeates eating. That would be important not only to empower patients' role during the treatment but also to contribute to a more effective result after recovery ${ }^{15}$.

\section{Deprivation}

Deprivation, a well-established characteristic of the disease, after recovery, slowly makes room to situations when there might be moments of exaggeration: "sometimes I think it's healthy to exaggerate" ( $\mathrm{Cl} 1 \mathrm{~A})$. During the $\mathrm{ED}$, this would be unthinkable: $\mathrm{Cl} 2 \mathrm{~A}$ and $\mathrm{Cl} 1 \mathrm{C}$ showed the restriction and exclusion of foods considered "fattening" during the ED.

Thereby, the use of light products could be considered a way of excluding "fattening" food, an artifice used by the subjects during the $\mathrm{ED}(\mathrm{Cl} 6 \mathrm{D})$. $\mathrm{Cl} 6 \mathrm{~A}$ highlighted the difficulty of the subjects in stopping using light foods with specific allegations after they have recovered. The concern to maintain a lean body is also featured in this discourse, explaining its continued use. It is then possible to suppose that our respondents' desires, feelings, expectations, as well as the use of light/diet products are evidence of the restrictive practices established during the disease. Accordingly, Schebendach et al. ${ }^{19}$ found that persons recovered from AN who had a later poor outcome consumed less non-diet and other kinds of food considered "fattening", which highlights the importance of studying such behaviors. Surprisingly, literature referring to eating practices and choices made by persons who have recovered from AN is very scarce.

\section{Beauty dictatorship}

Food choices can be made based on what is considered more appropriate for the body size and its modulation. Such practices are "written" in the body, forming and shaping it in a specific way ${ }^{3}$. In this scenario, the dictatorship of beauty gains ground. It involves the need to be thin, setting aside individualities as well as biological and genetic limitations. It is assumed that those who fit the pattern are valued, and those who do not, are rejected ${ }^{20}$; also, it reinforces the idea that the body can be a source of pleasure, when consistent with the expected pattern, or a source of anxiety and shame when it does not ${ }^{3}$; accepting this fact directly influences food choices, as will be further explained.

The excessive amount of information conveyed regarding food and dieting and the fact that we live in a society which encourages hyper consumption of food creates a duality: eating can represent a banal act, and it can also lead to irreversible consequences ${ }^{2,3}$. Such situation contributes to individuals' anxiety and insecurity related to their food consumption. Consequently, movements of reaction are induced and may manifest, for example, the concerns with diet, increased interest in cooking and greater individual discipline regarding food ${ }^{2}$. These movements are easily described, especially by women; however, those who experience AN reflect an important extreme. For them, contradictions regarding body dissatisfaction and deviations on eating practices are significantly enlarged and intensified ${ }^{20}$.

Accordingly, the discourses illustrate the respondents' desire of reaching a greater discipline regarding their diet, even after they have recovered, and a greater expectation to be healthier and natural (Cl 4A). Besides, their discourses show concern with a balanced and nutritionally adequate diet, as illustrated by CI 1B, 1D and 3B. It is important to point out how those concerns with healthier eating habits merge with the discourses of the beauty dictatorship; as Sudo and Luz $^{21}$ assert, esthetic becomes the socio-cultural criteria to determine "being healthy".

\section{Food competence}

Studies evidence the existence of inner and outer clues which establish different responses when faced with food exposure. The first refers to hunger, satiety and appetite; the second includes food availability and social interactions ${ }^{22}$. The speeches illustrate the subjects' reaction when confronting these experiences.

Regarding the inner experience of satiety, it was observed the respondents' difficulty in realizing when they were satisfied (CI 5B, 5C and 5D). Differently, CI 5A e 5E showed a contrary statement: "I stop when I'm satisfied".

It is known that food restriction represents a shift in the homeostatic processes that moderate food and body weight ${ }^{23}$. It is well established that, in such cases, one eats higher amounts of food when available ${ }^{24}$. It is not possible to assert that the individuals ingest an amount of food higher than usual nowadays, but, a great fear of feeling hungry was observed (CI 1C).

In turn, the perception and managing of hunger are important elements that lead to a normal appetite ${ }^{25}$. From $\mathrm{Cl} 2 \mathrm{E}$, it was seen that, during the $E D$, there was a connection between pleasure and hunger feeling. During $A N$, hunger is experienced as a temptation to lose control: its denial becomes a symbol of triumph and purity, and its control a source of euphoria, accomplishment and pleasure ${ }^{3}$. Yet, CI 1C showed that after recovery this association was lost, making room for a negative feeling linked to hunger.

Among ordinary individuals, the outer experience of social interaction seems to promote higher food ingestion ${ }^{5,26}$, to increase the time spent at the table and to promote disinhibition ${ }^{27}$. Differently, the discourses showed that the social interaction during the mealtime was, and still is, an inciting of discomfort to the subjects: "I didn't feel pleasure staying at the table" (CI 2C). Likewise, $\mathrm{Cl} 1 \mathrm{E}$ showed that the subjects' preference for having the meals alone remains 
even after they have recovered. This reinforces the need for approaching the emotional and social functions of food during treatment, and for promoting the social integration of the patients ${ }^{15}$.

Satter ${ }^{22}$ developed the eating competence model, based on food behavior and attitudes. According to the model, competent eaters are positive, confident, comfortable, and flexiblewhen itcomes to eating practices. Such attitudes allow them to be attuned to outer and inner experiences related to eating ${ }^{22}$. Inner experiences determine feelings of comfort or conflict when exposed to food; outer experiences, which include food availability and social interactions, interfere on the eating practices inherent in those experiences.

Thus, competent attitudes are based on the individual ability to trust on feelings, and to accept and be comfortable with the pleasures of food and the satiety experience ${ }^{22}$. Thereby, it is possible to state that some individuals have developed a higher degree of eating competence after recovery, but overall, that seems to be low, considering that few speeches reported a positive, comfortable and flexible attitude towards food.

\section{Importance of food}

Food is central to individuals' identity, and is, at the same time, a source of ambivalence, since food intake implies not only a risk, but also hope to become different based on what is eaten ${ }^{2-4}$.

Thus, the decision of what to eat can be entangling not only for embodying aspects as convenience and responsibility, but for representing identity conflicts ${ }^{4}$. It is a complex process that permeates social interactions; it influences health, and it is a source of pleasure, but also of anxiety and fear ${ }^{5}$.

Nunes and Vasconcelos ${ }^{28}$ observed that for patients with AN food represented torture, terror, fear and decadence. Moreover, they reported it as being a drug, an obligation, something that takes their freedom away. Long et al.18 reported their interviewees wished to escape and disappear during the mealtime.

In the present study, the discourses demonstrated a transition from an indifferent $(\mathrm{Cl} 7 \mathrm{~A}$ and $6 \mathrm{D})$ or negative feeling related to food ( $\mathrm{Cl} 2 \mathrm{~A}$ and $2 \mathrm{~B})$, into something that became a tool to live well and to accomplish future projects (Cl 7C) after recovery. Conversely, it was also possible to notice that it is a phase of adjustment (Cl 7B), and that food still is a source of anxiety; the need for controlling and choosing different kinds of healthy food still remains (CI 7D).

Some of these findings could also be observed by Jenkins and Ogden ${ }^{29}$ : the interviewees reported ambivalent feelings during the recovering process; this was a difficult moment, which involved feelings of distress and anxiety, but also positive ones, since their self-awareness was enhanced, and they were feeling stronger, and enjoying life, as observed in the present study in the speeches after recovery.

Besides, the subjects reported that recognizing the disadvantages caused by the disease was also fundamental for their recovery. In this study, the speeches met such considerations ( $\mathrm{Cl} 7 \mathrm{C}$ ), implying that when sick the subjects could not accomplish many of their projects.

A review on qualitative studies involving the treatment of $\mathrm{AN}^{30}$ found that the fear of changes, ambivalence and anxiety limited the recovering process, which was also observed in the discourses of this study (CI 7D). While in the review these feelings were related to a subjects' wish to remain thin, in the speeches of the present study they were related to the need to strictly eat healthy food, following a routine.

Lamoureux and Bottorff ${ }^{31}$ noticed that the AN was the solution found by the individuals to deal with daily challenges and demands; therefore, restriction and weight loss were the way found by the subjects to establish control and identity ${ }^{32,33}$. Among the challenges cited when in recovery, a feeling of abandonment and exposure were observed, considering that once recovered, the familiar feeling of security made room for insecurity and fear, making them feel vulnerable and susceptible to relapses.

Accordingly, Cl 7E of the present study meets the challenges described. The line implies that food has no influence on the subjects' life, what may suggest that the contact with food equals vulnerability, insecurity and fear. Not listing food as a priority may be the way they found to feel safe and protected against the unknown and possible relapse. Furthermore, it may indicate a low eating competence, since their distance from food exemplifies a negative, inflexible and not comfortable attitude towards it.

\section{Food cacophony}

Currently, there is countless information about food: public health policies, nutritional prescriptions and prohibitions, medicalization and individualization of food and eating, everything amplified by the media. Thus, Fischler ${ }^{34}$ proposed the concept of food cacophony: the combination of those multiple discourses creating a "noise" for their understanding and, frequently, leading to contradictory data ${ }^{34}$.

Consequences of this cacophony were noticed in our discourses, mainly in the period after the ED. There was a great association between food and negative feelings when related with possible injuries to the body and expressed the respondents' wishes to establish a more natural, healthier and nutritionally adequate diet. One example refers to meat. While some subjects reported they would like to eat less meat $(\mathrm{Cl} 4 \mathrm{~B})$, others reported they would like to eat more meat $(\mathrm{Cl} 4 \mathrm{D})$. The same occurs with light and diet food (Table 4), which were seen as positive by some (Cl $6 \mathrm{~A})$, as not healthy by others ( $\mathrm{Cl} 6 \mathrm{~B})$ and as "relative" $(\mathrm{Cl} 6 \mathrm{C})$ 
and "markers" of the ED (Cl 6D). In short, it was noted that there were contradictory discourses about food, especially regarding "what is necessary to eat", which is, according to Poulain ${ }^{35}$, the core of food cacophony. It stressed how dietetic rules are currently rooted in the speeches abovementioned. Apparently, subjects experience a duality between a remaining AN voice, which urges them to restrict their food intake, and a remaining treatment voice, which requires them to balance and adequate their food intake.

Some of the study limitations comprise the small sample size and the fact that the majority of the respondents had participated of the RISSCA. Nevertheless, the sample size fulfilled the saturation criteria, a crucial aspect of qualitative inquiries. It was also a varied sample, stressed by respondents' age amplitude, diversity of treatments received, duration of the disease and years of remission. That also reinforces the idea that, although the majority was part of RISSCA, they were a heterogenic group. The "snowball chain" methodology is sometimes criticized by some authors; however, it is appropriate when the target population is rare, interconnected and hard to be approached directly, as is the case of those who experienced the $\mathrm{AN}^{36}$.

\section{CONCLUSION}

This study analyzed how women recovered from AN, perceive and report their current eating practices, as well as their eating practices during the ED.

An important result is the diversity of eating practices after the recovery. While during the ED these practices were similar, marked by dietary restriction, after the ED they became diversified; some participants seem to have developed a higher eating competence, others still present similar practices to the ones developed during the AN, marked by control and restriction, even though not as intense as before. Furthermore, interviewees reported difficulty in noticing when satisfied, and social interaction still is something bothersome, meaning shame and discomfort.

While aspects regarding consumption need to be taken into account during the AN treatment, strategies that access eating practices aspects should be addressed as well. In the present study, some participants seem to have unchanged perceptions or a perception extremely supported by a biological and normative perspective. Understanding their eating practices could be important to empower treatment outcome and also understand and predict relapses.

Thereby, perceptions regarding eating practices could be addressed by professionals during their patients' treatment. Further studies could develop strategies to help increase food competence throughout the treatment and analyze aspects regarding the mealtime considered important by patients.

\section{INDIVIDUAL CONTRIBUTIONS}

Mariana Dimitrov Ulian - Collected the data and conceived the study, analyzed the findings and wrote the article.

Fernanda Baeza Scagliusi - Conceived the study, analyzed the findings and wrote the article.

All authors read, reviewed and approved the final version.

\section{CONFLICTS OF INTEREST}

There were no conflicts of interests.

\section{ACKNOWLEDGMENTS}

The authors acknowledge the participants for putting their trust on our work, the RISSCA (and specially its coordinator Natália Bonfim) for helping in the subjects' recruitment and the colleagues Roberto Manoel dos Santos and Marilia Zanella for helping in the text review and in the translation review, respectively. We also acknowledge the funding conceived by the Fundo de Auxílio aos Docentes e Alunos da Universidade Federal de São Paulo (FADA) and by the REUNI program.

\section{REFERENCES}

1. Cordás TA, Salzano FT. Aspectos gerais dos transtornos alimentares: características, critérios diagnósticos, epidemiologia e etiologia. In: Alvarenga M, Scagliusi FB, Philippi ST. Nutrição e transtornos alimentares: avaliação e tratamento. Barueri: Manole; 2011. p. 3-15.

2. Fischler C. Food, self and identity. Soc Sci Inform. 1998;27:275-92.

3. Lupton D. Food, the body and the self. London: Sage Publications; 1996

4. Belasco W. Food: The Key Concepts. Oxford: Berg Publishers; 2008.

5. Chamberlain K. Food and health: expanding the agenda for health psychology. J Health Psychol. 2004;9(4):467-81.

6. Espíndola CR, Blay SL. Long term remission of anorexia nervosa: factors involved in the outcome of female patients. PLOS ONE. 2013;8(2):1-6.

7. Schebendach J, Mayer LE, Devlin MJ, Attia E, Walsh BT. Dietary energy density and diet variety as risk factors for relapse in anorexia nervosa: a replication. Int J Eat Disord. 2012:45(1):79-84.

8. Crisp AH, Stonehill E, Fenton GW. The relationship between sleep, nutrition and mood: a study of patients with anorexia nervosa. Postgrad Med. 1971;47:207-13.

9. Poulain J-P, Proença RPC. Methodological approaches on the studies of food practices. Rev Nutr. 2003;16(4):365-86

10. Patton MQ. Qualitative Research and Evaluation Methods. 3.ed. Thousand Oaks: Sage; 2002.

11. Minayo MCS. 0 Desafio do Conhecimento: Pesquisa Qualitativa em Saúde. 12.ed. São Paulo: Hucitec; 2010.

12. DiCicco-Bloom B, Crabtree BF. The qualitative research interview. Med Educ. 2006;40:314-21.

13. Lefévre F, Lefévre AMC. 0 discurso do sujeito coletivo: um novo enfoque em pesquisa qualitativa (Desdobramentos). 2.ed. Caxias do Sul: Educs; 2005.

14. Sansone RA, Sansone LA. Personality pathology and its influence on eating disorders by Randy. Innov Clin Neurosci. 2011;8(3):14-8. 
15. Arnaiz MG. Learning to eat: establishing dietetic normality in the treatment of eating disorders. Food Cult Soc. 2009;12(2):191-215.

16. Lee S, Chan L, Kwok K, Hsu G. Relationship between control and the intermediate term outcome of anorexia nervosa in Hong Kong. Aust N Z J Psychiatry. 2005;39:141-5.

17. Souto S, Ferro-Bucher JSN. Práticas indiscriminadas de dietas de emagrecimento e o desenvolvimento de transtornos alimentares. Rev Nutr. 2006;19(6):693-704.

18. Long S, Wallis D, Leung N, Meyer C. "All eyes are on you": anorexia nervosa patient perspectives of in-patient mealtimes. J Health Psychol. 2012;17(3):419-28.

19. Schebendach J, Mayer LE, Devlin MJ, Attia E, Contento IR, Wolf RL, et al. Food choice and diet variety in weight-restored patients with anorexia nervosa. J Am Diet Assoc. 2011;111(5):732-6.

20. Scagliusi FB, Lourenço BH. A ditadura da beleza e suas consequências no discurso nutricional. In: Alvarenga M, Scagliusi FB, Philippi ST. Nutrição e transtornos alimentares: avaliação e tratamento. Barueri: Manole; 2011. p. 59-83.

21. Sudo N, Luz MT. 0 gordo em pauta: representações do ser gordo em revistas semanais. Ciênc Saúde Coletiva. 2007;12(4):1033-40.

22. Satter EM. Eating competence: definition and evidence for the Satter eating competence model. J Nutr Educ Behav. 2007;39(5):142-53.

23. Kessler DA. The end of overeating: taking control of the insatiable American Appetite. New York: Rodale Books; 2009

24. Polivy J, Herman CP. An evolutionary perspective on dieting. Appetite. 2006;47:30-5.

25. Dye L, Blundell J. Functional foods: psychological and behavioral functions. Brit J Nutr. 2002;88(2):187-211.
26. Eartmans A, Baeyens F, Bergh 0. Food likes and their relative importance in human eating behavior: review and preliminary suggestions for health promotion. Health Educ Res. 2001;16(4):443-56.

27. Toral N, Slater B. Abordagem do modelo transteórico no comportamento alimentar. Ciênc Saúde Coletiva. 2007;12(6):1641-50.

28. Nunes AL, Vasconcelos FAG. Transtornos alimentares na visão de meninas adolescentes de Florianópolis: uma abordagem fenomenológica. Ciênc Saúde Coletiva. 2010;15(2):539-50.

29. Jenkins J, Ogden J. Becoming 'whole' again: a qualitative study of women's views of recovering from anorexia nervosa. Eur Eat Disord Rev. 2011;20(1):1-9.

30. Espíndola CR, Blay SL. Anorexia nervosa treatment from the patient perspective: a metasynthesis of qualitative studies. Ann Clin Psychiatry. 2009;21(1):38-48.

31. Lamoureux MMH, Bottorff JL. "Becoming the real me": recovering from anorexia nervosa. Health Care Women Int. 2005;26(2):170-88.

32. Patching J, Lawler J. Understanding women's experiences of developing an eating disorder and recovering: a life-history approach. Nurs Inqu. 2009;16(1):10-21.

33. Nordbø RHS, Espeset EMS, Gulliksen KS, Skarderud F, Holte A. The meaning of selfstarvation: qualitative study of patients' perception of anorexia nervosa. Int I Eat Disord. 2006;39:556-64.

34. Fischler C. Gastro-nomie et gastro-anomie. Communications. 1979;31:189-210.

35. Poulain J-P. Sociologias da Alimentação. Florianópolis: Ed. da UFSC; 2004.

36. Liamputtong P, Ezzy D. Qualitative Research Methods. Victoria: Oxford; 2005. 